\title{
Inhibition of creatine kinase activity by ethylene oxide
}

\author{
M Matsuoka, H Igisu, N Inoue, H Hori I Tanaka
}

\begin{abstract}
Exposure of rats to $500 \mathrm{ppm}$ ethylene oxide for six hours a day, three times a week, for 12 weeks, lowered serum creatine kinase activity by more than $40 \%$. The only other change was a slightly decreased triglyceride concentration. After four weeks of exposure, neither aspartate aminotransferase nor lactate dehydrogenase activity in brain, spinal cord, and muscle was affected but creatine kinase activity was clearly inhibited. In vitro, ethylene oxide inhibited creatine kinase activity in brain homogenate and in a purified muscle enzyme preparation. Dithiothreitol did not counteract the effect of ethylene oxide. Though the amount of sulphydryl groups in purified creatine kinase was decreased considerably by exposure to ethylene oxide, the enzyme still showed moderate activity. Thus ethylene oxide inhibits creatine kinase activity in vivo and in vitro and the inhibition appears to be unrelated to the disruption of sulphydryl groups in the enzyme.
\end{abstract}

Ethylene oxide (EO) is a highly reactive gas widely used in the chemical industry and for the sterilisation of steam and heat sensitive materials in hospitals. Recently, cases of encephalopathy or polyneuropathy of employees engaged in sterilisation have been reported. ${ }^{1-6}$ Electrophysiological and morphological studies in these cases indicated neuroaxonal degeneration. ${ }^{36}$ Previous experiments in our laboratories have shown that chronic exposure to EO causes central peripheral distal axonal degeneration in rats. ${ }^{7}$ Nevertheless, the mechanism(s) underlying the neurotoxicity have not been elucidated.

Creatine kinase (CK) (ATP: creatine phosphotransferase, EC 2.7.3.2) is widely distributed in various tissues, particularly in the nervous system and muscles. ${ }^{8}$ Moreover, acrylamide and methyl $n$ butyl ketone which are typical toxins causing distal

Departments of Environmental Toxicology and Environmental Health Engineering, University of Occupational and Environmental Health, Kitakyushu 807, Japan

M Matsuoka, H Igisu, N Inoue, H Hori, I Tanaka axonopathy have been reported to inhibit CK. ${ }^{9}$ Therefore, we studied the effects of $\mathrm{EO}$ on this enzyme in vivo and in vitro.

\section{Materials and methods}

MATERIALS

Purified (crystalline) creatine kinase (from rabbit muscle) was obtained from Boehringer-MannheimYamanouchi (Tokyo, Japan). $\mathrm{CO}_{2}$ gas $(99.5 \%)$ and ethylene oxide gas (pure $\mathrm{EO} 20 \mathrm{Wt} \%, \mathrm{Co}_{2} 80 \mathrm{Wt} \%$ ) were purchased from Showa Tansan Co, Ltd (Tokyo, Japan). All other chemicals were reagent grade.

\section{ANIMALS AND TREATMENT}

Male Wistar rats weighing $160-180 \mathrm{~g}$ were used. The exposure chamber was made of stainless steel with a total inner volume of $1.0 \mathrm{~m}^{3}$. Air and $\mathrm{EO}$ gas were constantly introduced into the chamber through a mass flow meter. The concentration of $\mathrm{EO}$ in the exposure chamber was kept at $500 \mathrm{ppm}$ and monitored periodically by gas chromatographic analysis. Such an exposure caused peripheral neuropathy in rats after 13 weeks of exposure. ${ }^{7}$ One exposure lasted for six hours and the exposure was repeated three times in a week. Control animals were exposed to ambient air in the same manner. Water was given ad libitum except during exposure to EO. (Hence, the water and the food were not in contact with EO.) As exposure to EO suppresses food intake, to minimise the effect of nutritional difference, food intake was matched by pair feeding between exposure and control groups. Forty hours after the final exposure, animals were killed by decapitation. Blood was collected from the cervical veins and kept on ice. The brain, entire spinal cord, and a part of gastrocnemius muscles were immediately kept at $-40^{\circ} \mathrm{C}$.

\section{PREPARATION OF TISSUE}

Frozen tissues were thawed at $37^{\circ} \mathrm{C}$ for five minutes. Subsequent procedures were all carried out at $0-4^{\circ} \mathrm{C}$. Each tissue was homogenised with 9 vols of cold 20 $\mathrm{mM} \mathrm{NaHCO}{ }_{3}$ using a Potter-Elvehjem homogeniser; a Tefion pestle was used for brains $(800 \mathrm{rpm}, 7$ strokes), and a glass pestle for the spinal cords and muscles (400 rpm, 7 strokes). The muscle homogenates were centrifuged at $6000 \mathrm{rpm}$ for 30 minutes. Supernatants of muscle homogenate and the whole 
Table 1 Serum chemistry (mean \pm 02 SD) after 12 week exposure to ethylene oxide. (Number of samples in each group in parentheses)

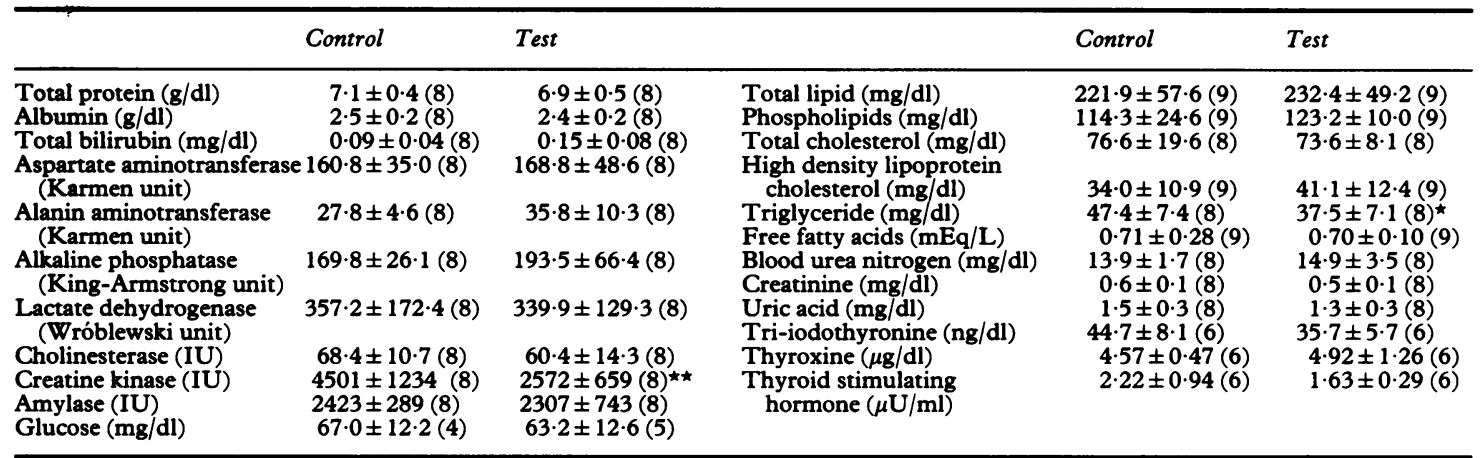

Difference from control: ${ }^{\star} p<0.05 ;{ }^{\star \star} p<0.005$.

homogenates of brain and spinal cord were used for enzyme assay.

\section{ANALYTICAL PROCEDURE}

Activities of $\mathrm{CK}$, aspartate aminotransferase (ASAT) (L-aspartate: 2-oxoglutarate aminotransferase, EC 2.6.1.1), and lactate dehydrogenase (LDH) (L-lactate: NAD oxidoreductase, EC 1.1.1.27) in tissue were determined using the method of Oliver, ${ }^{10}$ Karmen et $a l,{ }^{11}$ and Wróblewski and LaDue $^{12}$ respectively. Serum chemistry (total protein, albumin, total bilirubin, ASAT, alanin aminotransferase, alkaline phosphatase, LDH, cholinesterase, CK, amylase, glucose, total lipid, phospholipids, total cholesterol, high density lipoprotein cholesterol, triglyceride, free fatty acids, blood urea nitrogen, creatinine, uric acid) was determined by Hitachi H-736 autoanalyser. Tri-iodothyronine, thyroxine, and thyroid stimulating hormone in serum were determined by radioimmunoassay.

For in vitro studies, homogenates of the brain from male Wistar rats were suspended in $20 \mathrm{mM} \mathrm{NaHCO}_{3}$ $(0.33 \mathrm{mg} / \mathrm{ml})$ with or without $10 \mathrm{mM}$ dithiothreitol (DTT) and were bubbled with $\mathrm{N}_{2}(100 \%), \mathrm{CO}_{2}$ $(99.5 \%)$, and $\mathrm{EO}\left(\mathrm{EO} 20 \mathrm{Wt} \%, \mathrm{CO}_{2} 80 \mathrm{Wt} \%\right.$ ) gas for two minutes. After being placed on ice for 30 minutes, the activity of $\mathrm{CK}$ was determined. For the determination of ASAT and LDH, homogenates of rat brain were made thus: $1.0 \mathrm{mg} / \mathrm{ml}$ for ASAT and $3.3 \mathrm{mg} / \mathrm{ml}$ for $\mathrm{LDH}$.

Crystalline CK from rabbit muscle $(1 \mathrm{mg} / \mathrm{ml})$ was dissolved in $20 \mathrm{mM} \mathrm{NaHCO}$ and bubbled with $\mathrm{EO}$ gas for three, 10, 30, and 60 seconds. After standing on ice for 10 minutes, the amount of sulphydryl groups and CK activity were determined. The sulphydryl group was measured by the method of Ellman using cysteine as the standard. ${ }^{13}$

The protein was measured by the method of Lowry et al. ${ }^{14}$ Statistical differences were examined by Student's $t$ test.

\section{Results}

\section{IN vivo STUDIES}

Body weight did not differ between exposed and control groups. The exposed rats began to show ataxic gait at the sixth week of the experiment.

The CK activity in the serum was lowered by more than $40 \%$ after 12 weeks of exposure (table 1 ). Serum triglyceride levels decreased by $20 \%$, but no other biochemical alterations were found (table 1 ).

The CK activity was also inhibited in brain, spinal cord, and muscle after four weeks exposure but no inhibition was found in ASAT and LDH from these tissues (table 2). After 12 weeks exposure, CK activity in the brain was more suppressed than after four weeks.

After a single exposure (six hours), $\mathrm{CK}$ in the brain was suppressed by approximately $10 \%$. The enzyme activity recovered gradually with time (data not shown).

Table 2 Effects of exposure to ethylene oxide on enzyme activities in tissues (mean $\pm S D$ ). (Number of samples in each group in parentheses)

\begin{tabular}{|c|c|c|c|}
\hline & $C K$ & $A S A T$ & $L D H$ \\
\hline \multicolumn{4}{|l|}{ Brain: } \\
\hline $\begin{array}{l}\text { Control (4) } \\
\text { Test (6) } \\
\text { Control (6)† } \\
\text { Test (6) } \dagger \\
\text { Spinal cord: }\end{array}$ & $\begin{array}{l}315 \cdot 9 \pm 10 \cdot 8 \\
232 \cdot 0 \pm 4 \cdot 5^{\star} \\
298 \cdot 1 \pm 31 \cdot 3 \\
203 \cdot 2 \pm 21 \cdot 0^{\star}\end{array}$ & $\begin{array}{l}72 \cdot 1 \pm 1 \cdot 6 \\
71 \cdot 7 \pm 2 \cdot 5\end{array}$ & $\begin{array}{l}136 \cdot 5 \pm 6 \cdot 7 \\
136 \cdot 5 \pm 4 \cdot 6\end{array}$ \\
\hline $\begin{array}{l}\text { Control (4) } \\
\text { Test (6) } \\
\text { Muscle: }\end{array}$ & $\begin{array}{l}195 \cdot 1 \pm 9 \cdot 5 \\
150 \cdot 8 \pm 3 \cdot 3^{\star}\end{array}$ & $\begin{array}{l}40 \cdot 8 \pm 2 \cdot 3 \\
40 \cdot 0 \pm 1 \cdot 5\end{array}$ & $\begin{array}{l}63 \cdot 4 \pm 1 \cdot 4 \\
63 \cdot 6 \pm 2 \cdot 8\end{array}$ \\
\hline $\begin{array}{l}\text { Control (4) } \\
\text { Test (6) }\end{array}$ & $\begin{array}{l}1854 \cdot 8 \pm 175 \cdot 5 \\
1101 \cdot 6 \pm 247 \cdot 3^{\star}\end{array}$ & $\begin{array}{l}61 \cdot 8 \pm 5 \cdot 7 \\
59 \cdot 4 \pm 8 \cdot 2\end{array}$ & $\begin{array}{l}202 \cdot 6 \pm 22 \cdot 3 \\
219 \cdot 5 \pm 32 \cdot 9\end{array}$ \\
\hline
\end{tabular}

The activities of CK (creatine kinase), ASAT (aspartate aminotransferase), and LDH (lactate dehydrogenase) are expressed in terms of international unit/g tissue, Karmen unit/mg tissue, and Wróblewski unit/mg tissue, respectively.

$\star$ Significantly different from the control $(\mathrm{p}<0.001)$

†The organs were obtained after 12 weeks exposure. All other organs were obtained after four weeks exposure. 
Table 3 Effects of $\mathrm{N}_{2}, \mathrm{CO}_{2}$, and ethylene oxide on creatine kinase activity in brain homogenate

\begin{tabular}{lll}
\hline & $\begin{array}{l}\text { Activity } \\
\text { (IU/mg prot) }\end{array}$ & $\begin{array}{l}\text { Per cent } \\
\text { inhibition }\end{array}$ \\
\hline Control & $2.56 \pm 0.02$ & - \\
$+10 \mathrm{mM}$ DTT & $2.63 \pm 0.04$ & -2.7 \\
$+\mathrm{N}_{2}$ & $2.61 \pm 0.02$ & -2.0 \\
+ CO & $2.38 \pm 0.03$ & 7.0 \\
+ EO & $0.34 \pm 0.04$ & 86.7 \\
+ EO $+10 \mathrm{mM}$ DTT & $0.41 \pm 0.02$ & 84.0 \\
\hline
\end{tabular}

Homogenates of the rat brain $(0.33 \mathrm{mg} / \mathrm{ml})$ with or without dithiothreitol (DTT) were bubbled with $\mathrm{N}_{2}, \mathrm{CO}_{2}$, or EO gas for two minutes and CK activity was determined. Each value is the mean $\pm S D$ of three experiments.

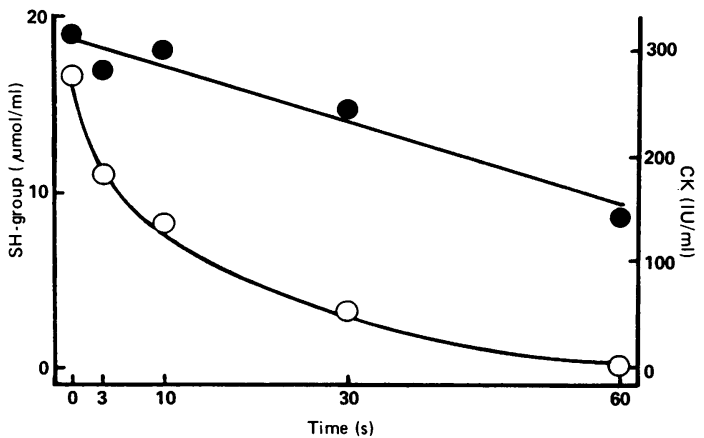

Effects of ethylene oxide on sulphydryl group $(O)$ and enzyme activity (O) of purified CK. Crystalline creatine kinase from rabbit muscle dissolved in $20 \mathrm{mM} \mathrm{NaHCO}$ $(1 \mathrm{mg} / \mathrm{ml})$ was bubbled with EO gas for three, 10,30 , and 60 seconds. Control experiments ( $O$ sec) were done in same manner without bubbling EO. Sulphydryl (SH) group and $C K$ activity were determined in duplicate and triplicate, respectively.

\section{IN VITRO STUDIES}

CK activity in the brain homogenate was not affected by bubbling with $\mathrm{N}_{2}$. Exposure to $\mathrm{CO}_{2}$ caused a slight suppression of CK activity but EO inhibited CK activity considerably (table 3 ). No inhibition was found in ASAT activity $(98.2 \pm 2.9 \%$ of control, $\mathrm{n}=3)$ and LDH activity (97.6 $\pm 1 \cdot 1 \%$ of control, $n=3$ ) when the brain homogenate was exposed to EO.

The inhibition of $\mathrm{CK}$ activity by $\mathrm{EO}$ was not counteracted by $10 \mathrm{mM}$ DTT (table 3). The sulphydryl groups in purified CK were considerably decreased by brief exposure to EO. Nevertheless, the decrease of CK activity was much less than that of the sulphydryl groups (figure).

\section{Discussion}

Because of its high explosiveness, EO is usually mixed with $\mathrm{CO}_{2}$ in sterilising processes, ${ }^{15}$ and it was in the present study. Our in vitro experiments, however, showed that the inhibition of $\mathrm{CK}$ was not influenced by $\mathrm{CO}_{2}$.

In cases of EO polyneuropathy routine laboratory studies are reported to be normal. ${ }^{1-5}$ In a cross sectional study of workers with potential occupational exposure to EO, haematological and biochemical studies (total bilirubin, alkaline phosphatase, LDH, ASAT, alanine aminotransferase, $\gamma$ GTP, BUN, and serum creatinine) showed no significant difference between the potentially exposed and unexposed groups. ${ }^{16}$ In these studies little attention was paid to CK activity. We found that exposure to EO causes suppression of serum CK activity, whereas none of the other serum enzymes we examined was inhibited. It is well known that serum CK activity is affected by thyroid status; serum CK activity decreases in hyperthyroidism and increases in hypothyroidism. After 12 weeks exposure, however, there were no alterations in serum triiodothyronine, thyroxine, and thyroid stimulating hormone, showing that thyroid function was not impaired by exposure to EO. Furthermore, our in vitro study indicated that $\mathrm{EO}$ can attack $\mathrm{CK}$ directly.

The level of ATP seems to be important to maintain normal function of the nervous system. For instance, fast axonal transport, which delivers essential materials to different parts of the nerve cells, is an energy (ATP) requiring process ${ }^{17}$ and the ATP levels in tissues are partially conserved by CK with phosphocreatine as the phosphate donor. ${ }^{18}$ Therefore, if CK activity is inhibited, it may cause dysfunction of the nervous system. We cannot conclude, however, that the inhibition of CK activity is the sole cause of encephalopathy or neuropathy because there is a possibility that EO impairs other important enzyme(s) or structure(s) in the nervous system.

$\mathrm{CK}$ has cysteine residues in its active site. ${ }^{8}$ In our in vitro study $E O$ induced inhibition of $C K$ was not counteracted by DTT, a protective agent for sulphydryl groups. This is in contrast with the suppression of the effects of acrylamide or methyl $n$-butyl ketone by DTT. ${ }^{9}$ There is, however, a possibility that EO acted on residues other than cysteine. Though EO decreased the amount of sulphydryl groups considerably, CK still retained its activity. Thus it appears that the sulphydryl groups that were attacked by EO may not be concerned directly in the catalytic action of CK.

To monitor human exposure to EO, measurement of the haemoglobin-histidine alkylation product, $\mathrm{N}^{\mathrm{t}}$-(2-hydroxyethyl)histidine has been proposed, ${ }^{19} 20$ although the background level of this product apparently limits the sensitivity. ${ }^{21}$ Among the enzyme activities examined, $\mathrm{CK}$ activity was the most sensitive to EO. Since the concentration of EO used in our experiment was high, however, further studies are necessary to determine whether or not $\mathrm{CK}$ activity may be used clinically as an indicator of EO intoxication.

We thank $T$ Sakimura, $M$ Muramoto, and $S$ Ishimatsu for technical help. 
1 Gross JA, Haas ML, Swift TR. Ethylene oxide neurotoxicity: report of four cases and review of the literature. Neurology 1979;29:978-83.

2 Salinas E, Sasich L, Hall DH, Kennedy RM, Morriss H. Acute ethylene oxide intoxication. Drug Intell Clin Pharm 1981;15:384-6.

3 Kuzuhara S, Kanazawa I, Nakanishi T, Egashira T. Ethylene oxide polyneuropathy. Neurology 1983;33:377-80.

4 Finelli PF, Morgan TF, Yaar I, Granger CV. Ethylene oxideinduced polyneuropathy. A clinical and electrophysiologic study. Arch Neurol 1983;40:419-21.

5 Zampollo A, Zacchetti O, Pisati G. On ethylene oxide neurotoxicity: report of two cases of peripheral neuropathy. Ital J Neurol Sci 1984;V:59-62.

6 Schröder JM, Hoheneck M, Weis J, Deist H. Ethylene oxide polyneuropathy: clinical follow-up study with morphometric and electron microscopic findings in a sural nerve biopsy. $J$ Neurol 1985;232:83-90.

7 Ohnishi A, Inoue N, Yamamoto T, et al. Ethylene oxide induces central-peripheral distal axonal degeneration of the lumbar primary neurones in rats. Br J Ind Med 1985;42:373-9.

8 Bais R, Edwards JB. Creatine kinase. CRC Crit Rev Clin Lab Sci 1982;16:291-335.

9 Lapin EP, Weissbarth S, Maker HS, Lehrer GM. The sensitivities of creatine and adenylate kinases to the neurotoxins acrylamide and methyl n-butyl ketone. Environ Res 1982;28:21-31.

10 Oliver IT. A spectrophotometric method for the determination of creatine phosphokinase and myokinase. Biochem $J$ 1955;61:116-22.

11 Karmen A, Wróblewski F, LaDue JS. Transaminase activity in human blood. J Clin Invest 1955;34:126-33.

12 Wróblewski F, LaDue JS. Lactic dehydrogenase activity in blood. Proc Soc Exp Biol Med 1955;90:210-3.
13 Ellman GL. Tissue sulfhydryl groups. Arch Biochem Biophys 1959;82:70-7.

14 Lowry OH, Rosebrough NJ, Farr AL, Randall RJ. Protein measurement with the folin phenol reagent. J Biol Chem 1951;193:265-75.

15 Boucher RMG. Advances in sterilization techniques. State of the art and recent breakthroughs. Am J Hosp Pharm 1972;29: 661-72.

16 Currier MF, Carlo GL, Poston PL, Ledford WE. A cross sectional study of employees with potential occupational exposure to ethylene oxide. $B r J$ Ind Med 1984;41:492-8.

17 Ochs S, Smith CB. Fast axoplasmic transport in mammalian nerve in vitro after block of glycolysis with iodoacetic acid. $J$ Neurochem 1971;18:833-43.

18 Bradford HF. Brain glucose and energy metabolism: the linkage to function. In: Bradford HF, ed. Chemical neurobiology. An introduction to neurochemistry. New York: W H Freeman and Company, 1986:118-54.

19 Calleman CJ, Ehrenberg L, Jansson B, et al. Monitoring and risk assessment by means of alkyl groups in hemoglobin in persons occupationally exposed to ethylene oxide. J Environ Pathol Toxicol 1978;2:427-42.

20 Farmer PB, Bailey E, Gorf SM, et al. Monitoring human exposure to ethylene oxide by the determination of haemoglobin adducts using gas chromatography-mass spectrometry. Carcinogenesis 1986;7:637-40.

21 Van Sittert NJ, De Jong G, Clare MG, et al. Cytogenetic, immunological, and haematological effects in workers in an ethylene oxide manufacturing plant. $B r J$ Ind Med 1985;42: 19-26.

Accepted 10 March 1989
The British Journal of Industrial Medicine welcomes correspondence relating to any of the material appearing in the journal. Results from preliminary or small scale studies may also be published in the correspondence column if this seems appropriate. Letters should be not more than $\mathbf{5 0 0}$ words in length and contain a minimum of references. Tables and figures should be kept to an absolute minimum. Letters are accepted on the understanding that they may be subject to editorial revision and shortening.

The journal now also publishes editorials which are normally specially commissioned. The Editor welcomes suggestions regarding suitable topics; those wishing to submit an editorial, however, should do so only after discussion with the Editor. 